Author: H Ojambo

DECENTRALISATION IN AFRICA: A CRITICAL REVIEW OF UGANDA'S EXPERIENCE

2012 VOLUME 15 No 2

http://dx.doi.org/10.4314/pelj.v15i2.4 


\section{DECENTRALISATION IN AFRICA: A CRITICAL REVIEW OF UGANDA'S EXPERIENCE}

H Ojambo*

\section{Introduction}

Uganda's experience with decentralisation is as highly acclaimed as it is criticised. Though regarded by some commentators as one of the most ambitious forms of devolution of power among the developing countries, it is also greatly criticised for its failure to deliver on its promises. According to Steiner, the scale and scope of the transfer of powers and responsibilities to the local level in Uganda's decentralisation reform is exceptional among developing countries. ${ }^{1}$ On their part, James and Francis have described it as "one of the most far-reaching local government reform programmes in the developing world." Mitchinson, in the same vein, contends that Uganda's decentralisation programme "is one of the most radical devolution initiatives of any country at this time." ${ }^{3}$

But the quest for the fruits of decentralisation appears to be only increasing. As Tumushabe et al have lamentably observed: ${ }^{4}$
Almost two decades later, the quality of public service delivery is less than desirable; district local governments with no financial resources of their own have become mere agents of the centre while the accountability mechanisms for good governance and public service delivery are either non-existent or malfunctional.

Other commentators view Uganda's decentralisation programme as more of a political gimmick than a genuine effort to promote democracy and good governance: ${ }^{5}$

\footnotetext{
* Henry Ojambo. S.J.D. \& LLM, University of Toronto. Lecturer, Makerere University; Partner, M/s Ojambo \& Ojambo Advocates, Kampala, Uganda hojambo@law.mak.ac.ug. The author extends appreciation for research assistance to Ms. Barbra Nahone Ajambo. This paper immensely benefited from comments made at the conference organised by the Africa Law Association (ALA) in cooperation with the Max Plank Institute (MPI) on "Legal Transformation in North Africa and Decentralisation in Africa" at Heidelberg, Germany.

1 Steiner Decentralisation in Uganda 1.

2 Francis and James 2003 World Development 325 (also cited in Steiner Decentralisation in Uganda 1).

3 Mitchinson 2003 Public Administration and Development 241 (also cited in Steiner Decentralisation in Uganda 1).

4 Tumushabe et al Monitoring and Assessing the Performance vi.
} 
...the creation of the districts did not follow any established parameters, neither was the process informed by administrative necessity or economic rationale. Instead the president announced their creation via presidential decrees, often to reward politicians threatening to withdraw support for the NRM, or punish those who had.

The principal objectives of decentralisation have historically included the promotion of accountability, transparency, efficiency in governance and service delivery, and the empowerment of the masses from grass-root levels through the promotion of the participation of individuals and communities in their governance. Decentralisation is therefore generally viewed as an effective mechanism of extending and deepening the democratisation process to the grass-roots in order to promote people's-based development in the context of a high regard for human rights.

Uganda's scenario presents a near-perfect fundamental contradiction between form and content. The great promise of improved accountability, efficiency in governance and the empowerment of the masses remains elusive in the country, notwithstanding the apparent commitment to the implementation of the decentralisation programme, at least at the formal level of the institutional and legal framework. According to a study ${ }^{6}$ commissioned by the World Bank, Uganda is ranked second to South Africa in almost all aspects of decentralisation in Africa. Ironically though, the same country is ranked among the most corrupt in the world with deplorable service delivery systems. $^{7}$ This paper thus seeks to examine Uganda's experimentation with decentralisation with a view to unearthing the subterranean constraints that continue to inhibit the delivery of the great promises of the system. The paper traces the historical background to Uganda's decentralisation process, outlines the current structure of Uganda's decentralisation and closely examines the challenges to the realisation of the promises of decentralisation.

5 Oloka-Onyango Decentralisation Without Human Rights? 6.

6 Ndegwa Decentralization in Africa.

7 According to the 2011 corruption perception report produced by a global graft watchdog, Transparency International, Uganda is ranked number 143 of the 183 countries considered. For a more detailed analysis of the poor service delivery system in Uganda's decentralisation system, see Tumushabe et al Monitoring and Assessing the Performance vi and Oloka-Onyango Decentralisation Without Human Rights? 6. 


\section{The rationale and historical background of decentralisation in Uganda}

Defined as the devolution of powers in terms of public authority, resources, and personnel from the central government to sub-national levels, decentralisation can take different forms. In some cases, decentralisation may denote the transfer of such power from the central government to a province or state, as in the case of federal systems, or could refer to the transfer of such powers to lower levels of government within a unitary system. For the rather obvious reason that Uganda has a unitary system of government, this paper will focus on decentralisation in a unitary system and particularly where powers are devolved from the central government to the lower-level local government. In Uganda's case, the analysis focuses on the devolution of powers from the central government to the district and the lower-level local governments, which include the sub-county, municipality, division and parish.

\subsection{The historical background of decentralisation in Uganda}

The history of decentralisation in Uganda can be traced way back to the colonial days. However, it was not until the rise of the National Resistance Movement (NRM) government to power under the leadership of Yoweri Kaguta Museveni ${ }^{8}$ that decentralisation was accorded the prominence it enjoys in the country today. It will be recalled that the British, in the execution of their indirect rule policy, established a hybrid system of administration in most of their colonies including Uganda, where some powers were granted to the native leaders while the colonial government reserved overriding powers through the representatives of the colonial government. In Uganda's case, this system of administration was exemplified by the African Native Authority Ordinance of $1919,{ }^{9}$ which provided for the powers and duties of African chiefs in the colonial administration. Under the Ordinance, chiefs were appointed at the village, sub-county and county levels with powers to collect taxes, preside over native courts, and maintain law and order. These chiefs were, however,

8 Museveni (the president of Uganda from 1986 to date) fought a guerilla war that brought him to power under a system of government known as the National Resistance Movement (NRM), commonly referred to as the Movement Government, which formed the first government under his leadership until 2001, when the country adopted a multiparty system of government. The name Movement was then adopted as the name of his political party, which continues to dominate Uganda's politics.

9 Entebbe, Government Priner 1919. 
accountable to the District Commissioner, the executive head of the district and the principal representative of the central government.

The Local Government Ordinance of $1949^{10}$ ushered in new changes by establishing the district as a local government unit with a fairly autonomous administration. Among the different organs of the district were the District Councils, which were comprised of elected members and were responsible for district administration. Notably, though, the central government still retained overriding powers over District Council decisions. Chiefs remained salaried local government officials who were responsible to the central government through the District Commissioner.

During the colonial times other administrative units were kingdoms which more or less operated as federal states within the system. By the time of independence in 1962 Uganda had 11 districts and four kingdoms. The independent Constitution of 1962 established a decentralised system with elements of both federalism and decentralisation in the governance system. While the kingdom of Buganda was granted federal status, others such as Ankole, Bunyoro, Toro and the territory of Busoga were accorded semi-federal status. The rest of the country, comprised of the districts of Acholi, Bugisu, Bukedi, Karamoja, Kigezi, Lango, Madi, Sebei and West Nile, was administered through Councils. ${ }^{11}$

The independence Constitution was abrogated in 1966. The successor Constitution of 1967 centralised powers. The overthrow of the post-independence Obote government by Idi Amin through a military coup led to the establishment of a military regime between 1971-1979 during which districts were dissolved and regional/provincial administrations led by Governors who were high-ranking military officers were established. The second Obote government (1980-1985) did not make any significant efforts to change the system. ${ }^{12}$ Thus Uganda gradually but steadily witnessed increased centralisation of powers through the various political regimes from independence until 1986, when the nascent NRM government initiated

10 The African Local Government Ordinance and District Council Proclamations and Regulations, 1949; Entebbe, Government Printer, 1949.

11 Tumushabe et al Monitoring and Assessing the Performance vi and Oloka-Onyango Decentralisation Without Human Rights? 6.

12 Oloka-Onyango Decentralisation Without Human Rights? 4-9. 
fundamental changes in local government which culminated in the enactment of the Local Government Statute of 1993 and the subsequent Local Government Act of 1997. Under the same regime, the 1995 Constitution, which adopted and further articulated the local government system of government, was promulgated. The current system of local government is by far more robust and elaborate than any other that was ever attempted in the country's history.

\section{$2.2 \quad$ Rationale}

The reasons for the adoption of the current system of decentralisation under Museveni were largely internal. Unlike the previous efforts, many of which took the form of the deconcentration ${ }^{13}$ of powers from the centre to lower levels of government through representatives of the central government, the current system of local government grants by far the widest and most robust devolution of powers. ${ }^{14}$ The adoption of such an ambitious system of local government is partly, and indeed largely, explained by Uganda's post-independence turbulent political history and the peculiar challenges that affected the NRM government in its early days.

Prior to the rise of the NRM government in 1986, Uganda's history had been characterised by recurrent political turbulence. Beginning with the overthrow of the first Obote regime by Idi Amin Dada through a military coup in 1971 and the subsequent military overthrow of Idi Amini's regime in 1979, through the successive short-lived governments that were established and overthrown in a matter of months between the end of Amin's government in 1979 and the second Obote government in 1981, Uganda largely experienced military leadership. Expectations of the restoration of democratic governance after the election of the second Obote government into power in 1980 were thwarted by the 1985 coup championed by Tito Okello Lutwa. The Tito Okello government lasted only a few months before it too was overthrown by the NRM rebel forces under the leadership of Museveni in 1986.

13 Deconcentration "involves the transfer of some powers and responsibilities to lower administrative units operated by officials appointed by the central authority, who implement defined functions under tight control." See Oloka-Onyango Decentralisation Without Human Rights? 6-7.

14 The structure of the current system of local government is discussed later in the paper. 
Throughout this post-independence period of political turmoil, Uganda experienced various socio-economic challenges ranging from endemic gross violations of human rights through economic plunder and decadence to outright lack of democratic governance. Upon its rise to power through an armed rebellion partly prompted by the then socio-economically decadent situation, the NRM government quite understandably made democratisation one of its major goals. This was vividly captured in one of Museveni's inaugural speeches when he asserted: ${ }^{15}$

The first point in our programme is the restoration of democracy. The people of Africa - the people of Uganda - are entitled to a democratic government. It is not a favour from any government. It is the right of the people of Africa to have democratic government; the sovereign power in the land must be the population, not the government. In our liberated zones, the first thing we started was the election of Village Resistance Committees. My mother, for instance cannot go to parliament but she can surely become a member of a Committee so that she too, can make her views heard. We have, therefore set up village, muluka (parish), gombolola (sub-county) and district committees ... but right now I want to emphasize that our first point in our political programme is democracy for the people of Uganda.

But it should be noted that the creation of local councils (committees) was not originally informed by the desire to create democratic institutions. As Steiner observes, "the local councils were originally established for political reasons and not with the aim of improving service delivery or reducing poverty. ${ }^{16}$ In fact, according to Mugabi, the explanation lay in considerations of political expediency. The long protracted war that brought the NRM government to power greatly weakened state organs in the entire country. In areas where war was directly waged government systems were literally non-existent, as the rebel forces had in some cases taken control of parts of such areas. This created an administrative vacuum especially in local governance, which the rebel forces addressed by appointing members of the local communities in the areas they controlled to fill the gaps in local administration. Resistance Councils comprised of members were accordingly created with both administrative and security mandates in their areas of jurisdiction. Thus: ${ }^{17}$

During the "bush war" of the early 1980s, the organs of the state were destroyed, thus creating a vacuum in local governance. The NRM had no spare manpower to

15 Mugabi 2004 unpan1.un.org 1-2.

16 Steiner Decentralisation in Uganda 9.

17 Mugabi 2004 unpan1.un.org 1-2. 
utilize as local administrators. Accordingly, local communities were requested to elect from amongst themselves, councils to perform the duties of the defunct agents and organs of the old state. However, the primary role of these councils was to resist infiltration - through a network of information gathering on the operations of the enemy and liaising with the NRM intelligence organs - hence the name "resistance councils".

Once in power, the NRM government embarked on steps aimed at improving and legally entrenching the resistance council system of administration for the reasons already stated - democratic governance, filling the gaps in administration created by the destruction of state organs during the war, and the promotion of security. Indeed, shortly after taking over power the Museveni government established a commission of inquiry into local government under the leadership of Mahmood Mamdani. A white paper was prepared and presented to government and henceforth the government vigorously embarked on decentralisation based on the resistance council system. By 1987 the government had enacted the Resistance Council's and Committees Statute (the RC Statute), which repealed part 1 of the Local Administration Act of 1967 and the Urban Authorities Act of 1964. The RC Statute marked the very beginning of the formal decentralisation process under the Movement government by transferring such powers as planning, decision making and the administration of justice to the community-based Resistance Council system.

Thus, the adoption of the system of democratisation through the devolution of powers can fairly largely be attributed to local factors. Nonetheless, the role of external factors cannot be underestimated. Undoubtedly, Uganda is part of the Third World that has been subjected to some pressure from the donor community to embrace decentralisation as a pathway to democratic governance. Quite compelling assumptions have always been made about the great potential of decentralisation in deepening democracy and these have rendered it a near-universal prescription for addressing the governance challenges faced in the developing world.

\subsection{Objectives of decentralisation}

If well implemented, decentralisation promises efficient and accountable governance through the increased involvement of the people in the way they are governed. That is, decentralisation promotes people's participation in important government 
functions such as decision making, the identification of problems, priority setting, planning and monitoring the implementation of any programmes, which in effect promotes and ensures the better allocation and utilisation of resources. It is also generally believed that when people are involved in their own governance through decentralisation, accountability on the part of office bearers is enhanced, hence leading to more efficient utilisation of public resources, which in turn promotes development. Decentralisation also promises greater respect for human rights through the involvement of people in the design, planning and implementation of government programmes/policies. Over all, decentralisation enhances the process of governance.

However, the extent to which any decentralised system will deliver these noble objectives depends on more than the mere adoption of the system. While the formal legal framework/structure of any given decentralised system is important in the determination of its success, other extraneous factors such as the level of people's awareness, the availability of the necessary resources and the commitment of the central government are usually critical in determining the degree of success. Uganda's experience with decentralisation is particularly intriguing given the manifest contradictions between the rather admirable formal legal framework, on the one hand, and the continued deplorable plunder of public resources, impunity, poor service delivery and the continued high rate of violation of human rights, on the other. Before a critical discussion of the challenges faced in the decentralisation process in Uganda is undertaken, the country's highly acclaimed decentralised structure deserves to be briefly discussed.

\section{The structure and functions of local government in Uganda}

Local government in Uganda is based on the district as the basic unit. Various local governments and administrative units resort within the district. The district council, which is comprised of elected members, is the highest political authority having legislative and executive powers within the district, and other councils in lower-level local government are also the highest political authorities in their jurisdictions. ${ }^{18}$

18 Section 3 Local Government Act of 1997 (LGA). 
The structure of local government in Uganda takes different forms depending on whether the administrative area in question is rural or urban. Other than Kampala City, which has a special local government administrative structure ${ }^{19}$, the local government system is comprised of a five-tier structure where, in rural areas, the village council (LC1) forms the lowest level, followed by the parish council (LC2), then the sub-county council (LC3), the county council (LC4), and at the top (the district) the district council (LC5). ${ }^{20}$ On the other hand, in urban districts the structure begins with the village council (LC1), then the ward or parish council (LC2), the municipal or town division (LC3), the municipality (LC4) and the district council (LC5/mayor). ${ }^{21}$

The district council is the basic local government unit while the municipal council, city division council, the municipal division council, and the town council are lower-level local governments. Both the district council and the lower-level local government units have corporate status with perpetual succession and a common seal, and they have independent legal personality in the sense that they can sue and be sued in their corporate name. On the other hand, the county council, the parish/ward council and the village council are merely administrative unit councils without corporate status and thus enjoy less autonomy in the local government system than the local government units. The functions of these administrative units are limited to dispute resolution, monitoring of the delivery of services, and assisting in the maintenance of law, order and security.

In their areas of jurisdiction, local government councils are mandated to perform a variety of state functions ranging from making development plans based on locally determined priorities, raising revenue, budgeting (on condition that all of their budgets are balanced), and appointing statutory commissions, boards and committees for personnel (District Service Commission), land (District Land Boards), procurement (District and Urban Tender Boards) and accountability (Local

19 Kampala, as the capital city, is governed under a special legislation, Kampala Capital City Authority Act of 2010 (KCCA). Though the City Council is the highest authority under KCCA, the executive functions are discharged by the Chief Executive Officer, who is appointed by the central government, while the Lord Mayor is the chief political officer and is elected, just like his counterparts in other districts, the LC5.

20 Section 3(2) LGA.

21 Section 3(4) LGA. 
Government Public Account Committees), to establish or abolish offices in the public service of the district, as well as to hire and manage personnel in addition to managing their own payroll and pension. Local governments are also vested with powers to provide such services as education (except tertiary education), health services (except referral hospitals), the construction of roads (except those under the central government), and ambulance services.

While the central government retains jurisdiction with respect to such areas as security - defence, law and order, mines, minerals, water resources, banks, citizenship, national parks, foreign relations, national elections and national plans - it also oversees the performance of local governments through the office of the Resident District Commissioner (RDC). Under section 71 of the Local Government Act, the RDC is mandated to represent the President and the Government in the district, coordinate the administration of government services in the district, advise the district chairperson on matters of national interest, monitor and inspect the activities of local government, sensitise the populace on government policies, draw the attention of the Auditor General to the need for special investigations where necessary, and advise the district chairperson to instruct the district internal auditor to carry out a special audit and submit the report to council. The RDC is also mandated to draw the attention of the Inspector General of government to a need to investigate any cases of mismanagement or the abuse of office, just as he could draw the attention of any relevant line ministry to the divergence from or noncompliance with the Government policy by any council in his jurisdiction.

The Local Government Act also provides for the office of the Chief Administrative Officer (CAO), who is appointed by the public service commission and serves as the head of the public service in the district, the head of the administration of the district council and also as the accounting officer of the district. The CAO is thus responsible for the implementation of all lawful decisions by the council; giving guidance to the local government councils and their departments; and supervising, monitoring and coordinating the activities of the district and lower council employees; and he acts as the liaison officer between the district and the Government. Both the office of the $\mathrm{RDC}$ and the CAO are represented at all lower levels of government. 
Financially, local governments are entitled to levy, charge and collect local taxes and fees as locally generated revenue. But they also receive grants of different kinds from the central government to supplement their meager revenue collections not only for local programmes but also for the purpose of enabling them to implement government plans at the local level. The different grants given to local government include conditional $^{22}$, unconditional ${ }^{23}$ and equalisation grants. ${ }^{24}$

All in all, therefore, Uganda's framework of local government entails three different forms of devolution of power, namely: 1) political decentralisation (as evidenced by the election of council members), 2) administrative decentralisation (as evidenced by the appointment of local administration personnel by council), and 3) fiscal decentralisation (as evidenced by the powers granted to local councils to raise local revenue and receive funds from the central government for the implementation of agreed-upon national programmes).

\section{The performance of the decentralised system in Uganda}

It is now over two decades since Uganda adopted decentralisation, a system of government considered as a pathway to improving governance in terms of democratisation and service delivery. Yet, as earlier noted, Uganda's level of accountability for public resources and service delivery remains deplorable. This rather ironic situation naturally raises questions about the performance of decentralisation in the country. According to Ndegwa's stocktaking analysis of Uganda's performance in the different aspects of decentralisation, the country appears to be in the best category on the continent. On political decentralisation, the main indicators of which include the number of elected sub-national tiers, the

22 Article 193(3) Uganda Constitution of 1995 defines conditional grants as consisting of monies given to local governments to finance programmes agreed upon between the government and the local governments, which monies are expended only for the purposes for which the grant was made and in accordance with the conditions agreed upon.

23 Article 193(2) Uganda Constitution of 1995 defines the unconditional grant as the minimum grant that shall be paid to local government to run decentralised services.

24 Article 193(4) Uganda Constitution of 1995 defines the equalisation grant as the money to be paid to local government for giving subsidies or making special provisions for the least developed districts, and provides that it shall be based on the degree to which the local government unit is lagging behind the national average standard for a particular service. 
existence of direct elections for local governments, and the turn-out and fairness of such elections, Uganda scores above 3 on a scale of $4 .^{25}$

Quite similarly, the country also scored quite an impressive 3 on a scale of 4 in terms of its administrative decentralisation, the indicators of which include the role of local administrative staff in the formulation of the development agenda and the delivery of services, the existence of a clear legal framework demarcating the roles of local and central government, and the institutionalisation of the principle of subsidiarity, where actual service delivery is delegated to and performed by localities and civil servants responsible to local authorities. ${ }^{26}$ Uganda also performed quite well in terms of its fiscal decentralisation, which was assessed on the basis of the amount of the fiscal transfers made from the central government to the localities as well as the proportion of public expenditure controlled by the localities. Uganda emerge the third out of the 30 countries analysed in the study with a 3.5 on a scale of 5 in this category.

If these findings are indeed anything to go by, how then does one account for the rather obvious state of decay of local administration, the poor service delivery, and wholesale plunder of public resources that continues to dog the country? It is indeed ironic, and quite baffling, that a country that seems to have even exceeded its expectations in the decentralisation process should also be among the worst performing in terms of accountability and service delivery in its governance system.

While it is certainly difficult to make a claim to having a perfect explanation for the current rather contradictory situation obtaining in the country, a look into the historical background to the adoption of decentralisation could possibly offer some insight. As earlier noted, and quite unlike the experience in other countries where the adoption of decentralisation has been externally driven ${ }^{27}$, Uganda's adoption of a system of devolution of power was partly and largely necessitated by considerations of political expediency. The days when security was a major concern for the NRM regime are long gone. Concerns about resources, be they fiscal or human, may still

25 Ndegwa Decentralization in Africa 3.

26 Ndegwa Decentralization in Africa 4.

27 Steiner acknowledges this fact when she notes: "... Uganda is different from many other countries where decentralisation was motivated by a fiscal crisis of the central government or by external conditionality." (Steiner Decentralisation in Uganda 9). 
apply but they no longer pose a threat to the government. The effect of this has been the reversal of the commitment to the system of local government by the central government, which now appears to espouse a desire to run the government more from the centre than through local governments, many of which are now proving problematic in the new multiparty political dispensation.

The introduction of multiparty politics in Uganda in the early 2000s engendered a new threat to the NRM government. Unlike the prior "enemy," who could be effectively checked through the Resistance council system, the multiparty system created a different type of "enemy" that could no longer be effectively combated/checked through a system of local council networks. With time, the new "enemy" in the form of the opposition has spread out and taken root in most of the districts, a fact that has shaken the trust once enjoyed between districts (when their councils were predominantly NRMS supporters) and the NRM government at the centre. In fact the discomfort between the NRM government and the local government system started to manifest itself in the early 1990s when opposition groups started to agitate for the restoration of multiparty politics. As Oloka-Onyango aptly notes: ${ }^{28}$

The claim that RCs were a system of "popular" selection based on the "individual merit" of the candidates who stood for office was severely undermined by the fact that the state (which was controlled by the NRM) intervened heavily in support of some candidates, while it actively decampaigned, intimidated and blackmailed others. The peak of hypocrisy was reached when President Museveni declared "We have won!" following the 1993 elections for the Constituent Assembly which were originally supposed to be run on an "no party" basis. Who was the "we" in such a situation?

With the restoration of multiparty politics and the steadily waning popularity of the NRM government amidst the rising popularity of the opposition, whose members dominate local councils in some districts, the NRM now finds itself at war for its own survival with the very system it created to bolster its political hegemony. With council members from different political parties comprising the local government councils at all levels, the NRM government finds itself in an unusual position where it can no longer effectively ensure control over local politics. In effect, the councils no longer

28 Oloka-Onyango Decentralisation Without Human Rights? 10-11. 
enjoy the trust they once wielded from government, and as a result it is hardly surprising that the forces of recentralisation have intensified over time. As the central government strives to ensure stricter control over the affairs of local governments, especially through fiscal and political interference, the concept of decentralisation is steadily losing meaning and giving way to the reconcentration of power in the central government.

Closely related to the loss of trust is the politicisation of the decentralisation process, which is another factor that could explain Uganda's rather paradoxical situation. The original purpose for the creation of resistance (local) councils having been rendered obsolete, the NRM government has skillfully but successfully been able to use the decentralised system for quite another purpose which has only served to weaken local governance further. Under the Constitution, new districts could be created on the basis of the necessity for effective administration and the need to bring services closer to people. Other considerations that ought to be taken into account in the creation of new districts include the means of communication, geographical features, the density of the population, economic viability, and the wishes of the people concerned. Evidently, all of the grounds required for the creation of new districts lack specificity and can quite easily be exploited, as indeed has been the case. The NRM government has tended to use the creation of districts both as a reward for its supporters and as a condition for support in areas where it has historically not enjoyed popular support. This politicisation of the decentralisation process has greatly undermined its performance. From only 38 districts in 1986 when NRM rose to power, Uganda now boasts over 100 districts. As Oloka-Onyango rightly observes: ${ }^{29}$

... the strategy of district proliferation has ... been adopted by President Museveni as a means of dispensing patronage, and ultimately of splintering challenges to central government hegemony and control.

By using the creation of districts as a reward for political support, the government has been steadily increasing its expenditure portfolio without necessarily balancing it with increased GDP, which has naturally affected the local governments' ability to

29 Oloka-Onyango (n 28 above) 6. 
improve on service delivery due to their limited funding. The local government system envisages a financial partnership with the central government in the sense that while the central government remains duty bound to fund national programmes through the local government, the local government too was expected to raise local revenue for the purpose of funding its budget. With limited funding and no reliable source of local revenue, the local governments have been reduced to mere agents of the centre. It is important to note that the government has been notorious in undermining the fiscal autonomy of local governments. For instance, originally the major source of revenue for local governments was graduated tax, which, for clearly political reasons, was abolished just before the 2006 elections. This created increased dependence of local governments on the central government, with the obvious effect of undermining the local governments' capacity to plan and perform effectively. As Steiner observes: ${ }^{30}$

... the principal problem with regard to local finance is that collection of local taxes and fees is extremely low... Reasons for this are manifold and include the politicisation of local taxes ...

She adds: ${ }^{31}$

... the problem of low tax collection is far from being resolved. Instead of improving local governments' capacity to collect taxes and fees, the central government recently abolished graduated personal tax ...

The lack of awareness of the masses and the incompetence of the local administrative staff and local politicians are yet other factors that have continued to undermine the performance of the local government system in Uganda. The claim that decentralisation promotes people's participation in the way they are governed is premised on the assumption that people understand their roles in the decentralised programme. One of the challenges evident in Uganda's decentralised programme is, however, that the government appears to operate under the illusion that people know their roles in the decentralised system, an assumption which is absurdly wrong, especially in a country where the illiteracy level is still quite high. Under the said illusion, districts have been created all over the country without conducting civic 
education to empower the masses for the purpose of meaningfully getting involved in local administration. The effect of this rather sporadic, radical approach to decentralisation, which entails a total shift in the manner in which governance is conducted, ${ }^{32}$ has led to a clear lack of consistency and compliance with the requirements under the decentralisation legal framework. As Steiner observes, "people have not fully understood what decentralisation is about and what their rights and duties are." 33 The lack of awareness among the masses has rendered the notion of decentralisation more of a myth than a reality since the envisaged people's participation in their governance remains too sketchy and almost meaningless. This is moreover compounded by the general lack of competent staff in local government: "both politicians and civil servants are often inadequately trained..."34

Perhaps the most revealing effect of the lack of awareness of the masses and the incompetence of local government staff is found in the planning process. Under the local government legal framework, ${ }^{35}$

... the planning cycle provides for a consecutive elaboration of plans starting at the lowest level so that the plan of each level can be integrated into the plan of the next higher level.

But this is rarely complied with. In a study conducted in Tororo district, it was found in the three sub-counties that were visited that none had submitted "their plan to the district even though the new fiscal year had already started." ${ }^{36}$ The ignorance and incompetence of the people and the local government staff are some of the reasons for the failure of compliance with the principles and procedures of decentralised governance: $:^{37}$

32 Decentralisation entails a drastic shift in the nature of governance in the sense that it marks a shift from the government's deciding what is best for the people to the people's telling government what is best for them. See Steiner Decentralisation in Uganda 16.

33 Steiner Decentralisation in Uganda 16.

34 Steiner Decentralisation in Uganda 13.

35 Steiner Decentralisation in Uganda 15.

36 Steiner Decentralisation in Uganda 15.

37 Steiner Decentralisation in Uganda 15. Other reasons for the poor compliance with local government procedures include mistrust of the capacity of lower-level local government levels and hence disrespect for their identified priorities; delays in the submission of their plans, and logistical constraints. 
Ignorance of procedures among the officials in charge can represent the source of the problem... Many officials simply do not understand the rules of the game, and nobody at the local level is informed about what is going on, who has which plans, and whether plans have been written at all.

Government inefficiency has combined with the old problem of corruption to exacerbate matters. I have been told by many people who work in local government that government usually delays sending grants to local governments. By the time the money is received, the time for some of the planned activities would have passed. In such situations, the local governments have to choose between fabricating records to justify the expenditure of the money or sending the unutilised funds back to central government. While the latter would seem the right option to take, the reality is different: sending money back to the central government is usually construed as a failure on the part of the affected local government and could easily adversely affect future funding. The effect of this government inefficiency has not only been the undermining of service delivery by local governments but also the promotion of corruption.

\section{Conclusion}

The ironic outcome of Uganda's policy of decentralisation speaks to the challenges faced generally in the developing world. Decentralisation as a concept is not just about form, in the sense of developing a good legal and institutional framework, as has taken place in Uganda; it is also about content and process. The contradictions that characterise the Ugandan system of decentralisation are explained by factors that require effective mechanisms to address them. The challenges that continue to inhibit the performance of Uganda's decentralised system of governance are peculiar to Uganda's political history and facing up to them will certainly require a change of heart among the government leadership at the very least, or a change of regime. A true commitment to democratic values, where the leadership believes in the genuine empowerment of the masses, is critical to the effective performance of Uganda's decentralised system. 


\section{Bibliography}

Francis and James 2003 World Development

Francis $\mathrm{P}$ and James $\mathrm{R}$ "Balancing Rural Poverty Reduction and Citizen Participation: The Contradictions of Uganda's Decentralisation Program" 2003 World Development 325-337

Mitchinson 2003 Public Administration and Development

Mitchinson $\mathrm{R}$ "Devolution in Uganda: An Experiment in Local Service Delivery" 2003 Public Administration and Development 241-248

Ndegwa Decentralization in Africa

Ndegwa SN Decentralization in Africa: A Stocktaking Survey (World Bank Washington DC 2002)

Oloka-Onyango Decentralisation Without Human Rights?

Oloka-Onyango J Decentralisation Without Human Rights? Local Governance and Access to Justice in Post-Movement Uganda (Huripec Kampala 2007)

Steiner Decentralisation in Uganda

Steiner S Decentralisation in Uganda: Exploring the Constraints for Poverty Reduction (GIGA Hamburg 2006)

Tumushabe et al Monitoring and Assessing the Performance

Tumushabe GW et al Monitoring and Assessing the Performance of Local Government Councils in Uganda: Background, Methodology and Score Card (ACODE Kampala 2010)

\section{Register of legislation}

African Native Authority Ordinance of 1919

Kampala Capital City Authority Act of 2010

Local Government Act of 1997 
Uganda Constitution of 1995

\section{Register of internet sources}

Mugabi 2004 unpan1.un.org

Mugabi E 2004 Uganda's Decentralisation Policy, Legal Framework, Local Government Structure and Service Delivery unpan1.un.org/intradoc/groups/public/documents/UN/UNPAN029080.pdf (date of use 12 Jan 2011)

\section{List of abbreviations}

CAO Chief Administrative Officer

KCCA Kampala Capital City Authority Act

LGA Local Government Act

NRM National Resistance Movement

RC Statute Resistance Council's and Committees Statute

RDC Resident District Commissioner 